\title{
Effects of soil type and farm management on soil ecological functional genes and microbial activities
}

\author{
Jennifer R Reeve ${ }^{1}$, Christopher W Schadt ${ }^{2}$, Lynne Carpenter-Boggs ${ }^{3}$, Sanghoon Kang ${ }^{4}$, \\ Jizhong Zhou ${ }^{4}$ and John P Reganold ${ }^{5}$ \\ ${ }^{1}$ Department of Plants, Soils, and Climate, Utah State University, Logan, UT, USA; ${ }^{2}$ Biosciences and \\ Environmental Sciences Division, Oak Ridge National Laboratory, Oak Ridge, TN, USA; ${ }^{3}$ Center for \\ Sustaining Agriculture and Natural Resources, Washington State University, Pullman, WA, USA; ${ }^{4}$ Institute \\ for Environmental Genomics and Department of Botany and Microbiology, University of Oklahoma, Norman, \\ OK, USA and ${ }^{5}$ Department of Crop and Soil Sciences, Washington State University, Pullman, WA, USA
}

\begin{abstract}
Relationships between soil microbial diversity and soil function are the subject of much debate. Process-level analyses have shown that microbial function varies with soil type and responds to soil management. However, such measurements cannot determine the role of community structure and diversity in soil function. The goal of this study was to investigate the role of gene frequency and diversity, measured by microarray analysis, on soil processes. The study was conducted in an agroecosystem characterized by contrasting management practices and soil types. Eight pairs of adjacent commercial organic and conventional strawberry fields were matched for soil type, strawberry variety, and all other environmental conditions. Soil physical, chemical and biological analyses were conducted including functional gene microarrays (FGA). Soil physical and chemical characteristics were primarily determined by soil textural type (coarse vs fine-textured), but biological and FGA measures were more influenced by management (organic vs conventional). Organically managed soils consistently showed greater functional activity as well as FGA signal intensity (SI) and diversity. Overall FGA SI and diversity were correlated to total soil microbial biomass. Functional gene group SI and/or diversity were correlated to related soil chemical and biological measures such as microbial biomass, cellulose, dehydrogenase, ammonium and sulfur. Management was the dominant determinant of soil biology as measured by microbial gene frequency and diversity, which paralleled measured microbial processes.

The ISME Journal (2010) 4, 1099-1107; doi:10.1038/ismej.2010.42; published online 8 April 2010

Subject Category: microbial population and community ecology

Keywords: GeoChip microarray; soil functions; organic farming
\end{abstract}

\section{Introduction}

Relationships between soil microbial diversity and soil function are the subject of much debate. Until recently, unification of community and process level information in the study of soil microbial ecology has been severely hampered by the complexity of soil systems and the inadequacy of available techniques for describing microbial community composition. Traditional approaches such as direct culturing only provide a limited view of the microbial community, as only a fraction of the microbial population is culturable (Torsvik et al., 1990). Subsequently, soil microbiologists have focused on evidence of processes and activity such as respiration and enzymatic transformation of

Correspondence: JR Reeve, Department of Plants, Soils, and Climate, Utah State University, 4820 Old Main Hill, Logan, Utah 84322, USA.

E-mail: jennifer.reeve@usu.edu

Received 17 December 2009; revised 5 March 2010; accepted 5 March 2010; published online 8 April 2010 added substrates. While measurements of soil processes give valuable insight into overall microbial-mediated transformations in soils, they do not provide satisfying information on mechanisms, microbial functional composition and diversity that underpin process level differences. Thus, relating microbial diversity and function to ecological processes remains a central question in the study of soil microbial ecology (Kelly, 2003; Fitter et al., 2005; Little et al., 2008).

Microarray technology has the potential to help elucidate the relationships between structure and diversity of microbial populations on soil function. Microarrays provide a high throughput means of quantifying information on thousands of gene sequences of multiple functional types in a single experiment (Rhee et al., 2004; Wu et al., 2006; He et al., 2007). Although microarrays are routinely used to monitor gene expression in pure cultures, challenges in the application of microarray techniques to environmental samples have until recently limited their application to answering concrete 
ecological questions. This is because of the difficulty in extracting DNA of sufficient purity from soils and sediments, and poor or inconsistent sensitivity and specificity for diverse orthologous gene sets. Despite these challenges, exhaustive testing in recent years has determined that functional gene arrays (FGAs) are quantitative and can effectively differentiate between sequences when strict controls on homology and other probe characteristics are implemented (Rhee et al., 2004; Liebich et al., 2006; He et al., 2007; Wu et al., 2008). In addition, random amplification of extracted DNA has now made it possible to analyze microbial communities using sub-nanogram quantities of DNA extracted from extremely low biomass waters, soils and sediments (Wu et al., 2006, 2008), also alleviating many issues with inhibitors that resulted from concentrating DNA samples.

In this study, we used soils collected from agroecosystems characterized by contrasting management (organic vs conventional) and soil type (coarse vs fine-textured) to explore relationships between soil function and microbial populations and diversity using an FGA termed GeoChip. Studies using FGAs for the elucidation of specific ecological questions are still rare. While several studies have compared results from FGAs with other molecular techniques with a small total number of samples (Koizumi et al., 2002; Loy et al., 2002; Bodrossy et al., 2003; Rhee et al., 2004), we know of only one study comparing FGAs with soil processes and enzyme activities on the landscape level (Yergeau et al., 2007) and none employing a randomized replicated statistical design to investigate the impact of management and soil type on soil function and microbial diversity. We sampled soils in 2005 from eight adjacent pairs (replicates) of commercial organic and conventional strawberry fields. We hypothesized that soil processes, microbial abundance and diversity would be greater under organic management but that soil type would have a greater overall effect on microbial populations than management. Second, we hypothesized that soil microbial processes would be correlated with functional gene abundance and diversity.

\section{Materials and methods}

\section{Study area}

Eight pairs of side-by-side commercial organic and conventional strawberry farm fields were selected in the Watsonville area, the dominant strawberry growing region of California, USA. In turn, California is the leading producer in the United States, accounting for $87 \%$ of the nation's strawberry production, with nearly $5 \%$ of its total strawberry acreage in organic production (California Strawberry Commission, 2009). The Watsonville area annually grows strawberries on about 5000 hectares, accounting for almost $40 \%$ of the strawberry acreage in the state (California Strawberry Commission, 2009). This large strawberry growing region provided this study with two different farming systems (organic and conventional) but also with two different soil textural types, coarse-textured and fine-textured. Details of the organically and conventionally managed agroecosystems and the soil types are in Supplementary Information. Strawberry fields were selected across the Watsonville area on the basis of grower interviews and on-farm field examinations to ensure that all soil-forming factors, except management, were the same for each field pair, as described by Reganold et al. (1993). Each field pair had the same soil profile, soil type, soil classification and strawberry variety. Surface soil texture of each field pair was loamy sand or sandy loam (referred to as coarse-textured) or silty clay loam (referred to as fine-textured). Strawberries were grown on $30-\mathrm{cm}$ high mounded rows covered with plastic mulch.

\section{Soil sampling}

Soils were sampled in April 2005 from each of the 16 fields at 0-10 cm. Each sample consisted of 10-15 random subsamples, thoroughly homogenized. Each soil sample was then partitioned into three subsamples and shipped overnight to a commercial laboratory (Soiltest Farm Consultants, Moses Lake, Washington), to our laboratory at Washington State University, and to the Oak Ridge National Lab for analyses. Soil tested at Washington State University was stored at $4{ }^{\circ} \mathrm{C}$ and analyzed within 3 weeks and soil for microarray analysis at Oak Ridge National Lab was stored at $-20^{\circ} \mathrm{C}$.

\section{Soil analyses}

Details of soil chemical and physical properties are described in Supplementary Information. Additional soil chemical and biological parameters were analyzed as follows: total organic $\mathrm{C}$ and $\mathrm{N}$ were measured by combustion at $500{ }^{\circ} \mathrm{C}$ using a LECO CNS 2000; readily mineralizable carbon, basal respiration and substrate-induced respiration (microbial biomass) were measured following Anderson and Domsch (1978); dehydrogenase and phosphatase enzyme activity were measured after Tabatabai (1994); cellulase enzyme activities were measured after Alef and Nannipieri (1995a); chitinase activity was measured after Rössner (1995); nitrification potential was measured after Schmidt and Belser (1994); free living nitrogen fixation was measured by acetylene reduction (Alef and Nannipieri, 1995b); and denitrification was measured using denitrifier enzyme activity (Tiedje, 1994). All tests were performed on moist soil in triplicate.

\section{Microarray analysis}

We used a gene array termed GeoChip that contained more than 24000 oligonucleotide (50-mer) 
probes and targeted 10000 genes involved in nitrogen, carbon, sulfur and phosphorus transformations and cycling, metal reduction and resistance and organic xenobiotic degradation (He et al., 2007). Microarray genes in soil DNA samples were analyzed individually and within functional groups. A functional group is a group of genes involved in a certain function or process in the soil. In this study, the following 11 functional groups were targeted: nitrogen fixation, nitrification, denitrification, sulfite reduction, pesticide degradation, other organic xenobiotic degradation, metal reduction and resistance, and genes for the enzyme classes dehydrogenase, urease, cellulase, and chitinase. Details of soil DNA analyses using GeoChip are in Supplementary Information.

\section{Data analysis}

Slide images were converted to TIFF files and quantified using ImaGene software 6.0. (Biodiscovery Inc., Los Angeles, CA, USA) (Rhee et al., 2004). The signal to noise ratio of each probe on each slide was calculated as follows: $\mathrm{SNR}=$ (signal intensitybackground)/s.d. of the background. Background refers to the local background intensity, whereas the s.d. of the background was calculated across the whole slide. Data for any particular gene was removed unless it appeared with $\mathrm{SNR}>2$ at least twice across all replicates and treatments. When this condition was met individual SNR values of $<2$ were retained to maintain a continuous data set for statistical analysis. Where multiple probes were used for any particular gene per slide, the probe variant with the strongest signal was retained. After screening SNR, signal intensity values (SI) were then used as the data for sample comparison. Signal intensity values were normalized by averaging across technical replicates and imported into the SAS system for Windows version 9.1 (SAS Institute, Cary, NC, USA). Differences and similarities in gene abundance between treatment and soil type were tested using ANOVA and LSMeans in a split-plot incomplete block design with soil type as the whole plot factor and management as the subplot factor. The block design was incomplete because five field pairs were located on coarse-textured soil while only three were located on fine-textured soil. Uniquely detected genes and genera (means of SNR $>2$ and $P<0.05$ ) based on treatment and soil type were quantified. A Z-test of two proportions was used to compare numbers of unique genes and genera detected according to management and soil type. Gene diversity, overall and for each functional group, was calculated using Simpson's Reciprocal Index as $\mathrm{D}=1 /\left(\sum n(n-1) / N(N-1)\right.$ (where $n=$ the SI of any single gene with an SNR $>2$, and $N=$ the sum of all SIs with an SNR $>2$ on any one slide), then analyzed using ANOVA and LSmeans as above. Pearson correlation coefficients were determined between summed gene SI values or Simpson's diversity values for each functional group versus the corresponding soil activity measurement using the SAS system for Windows version 9.1 ANOVA (SAS Institute, Cary, NC, USA). Microarray and environmental data were also analyzed using non-parametric multivariate statistics, canonical correspondence analysis (CCA) and Mantel tests.

\section{Results}

Soil properties and process parameters

Soil process measures indicated significantly greater soil quality and microbial activity in organically managed soils than in conventionally managed soils. Compared with conventionally managed soils, organically managed soils contained significantly more total $\mathrm{C}$, total $\mathrm{N}$, sulfur, and microbial biomass; and supported greater dehydrogenase activity, acid and alkaline phosphatase activities and cellulase activity regardless of soil type. Denitrification potential was also greater in organically managed soils, but only within the fine-textured field pairs, while there was no difference between managements on coarse-textured soils (Table 1 and Supplementary Table S1). Organically managed soils also had a lower coefficient of respiration to microbial biomass $\left(\mathrm{qCO}_{2}\right)$, indicating the microbial biomass was more efficient or under less stress. Finetextured soils contained significantly greater total $\mathrm{C}$ and $\mathrm{N}$, greater Olsen phosphorus, potassium, sulfur, boron, copper, calcium, magnesium, total bases, clay, silt and denitrification potential than coarse-textured soils (Table 1 and Supplementary Table S1). Coarse-textured soils had significantly greater electrical conductivity, proportion of sand, cellulose activity and chitinase activity.

\section{Microarray analyses}

A total of 1711 genes with a SNR>2.0. on a minimum of two technical replicate slides across all samples were detected. The SI of 553 of these genes was significantly higher in organically managed soils, while none were significantly higher in conventionally managed soils (Figure 1a). A total of 505 genes differed significantly between soil types (Figure 1b), with 435 genes having significantly greater SI in coarse-textured soils and 70 having greater SI in fine-textured soils. Significantly more genes were endemic to organically farmed soils (233) as opposed to conventionally farmed soils $(2, z=14.5, P \leqslant 0.0001)$, whereas there were similar numbers of endemic genes detected in coarse- (75) as opposed to fine-textured soils $(88, z=0.9$, $P=0.812$ ). Statistical tests for interaction between soil type and management show that genes in these soils were more affected by management on finetextured soils than on coarse-textured soils, with 172 genes showing significant soil type by management interaction effects (Supplementary Figure S1). 
Table 1 Means $(n=8)$ of biological analyses of soil $(0-10 \mathrm{~cm}$ depth)

\begin{tabular}{|c|c|c|c|c|}
\hline Soil property ( $g^{-1}$ soil) & Coarse-textured soil & Fine-textured soil & Organic soil & Conventional soil \\
\hline Total carbon $\mu \mathrm{g}$ & 7177 & $14768^{\ddagger}$ & $12753^{*}$ & 9193 \\
\hline Total nitrogen $\mu \mathrm{g}$ & 640 & $1248^{\dagger}$ & $1010^{\dagger}$ & 789 \\
\hline Dehydrogenase $\mu \mathrm{g}$ TPF & 0.648 & 0.414 & $0.807^{\dagger}$ & 0.254 \\
\hline Readily mineralizable carbon $\mu \mathrm{g}$ & 15.3 & 15.0 & 17.8 & 12.5 \\
\hline Microbial respiration $\mu \mathrm{g}$ & 0.760 & 0.979 & 1.01 & 0.729 \\
\hline Microbial biomass $\mu \mathrm{g}$ & 138 & 137 & $204^{\ddagger}$ & 70.6 \\
\hline qCO2 (Mic. respiration Mic. biomass ${ }^{-1}$ ) & 0.007 & 0.009 & $0.005^{*}$ & 0.011 \\
\hline Acid phosphatase $\mu \mathrm{g}$ p-nitrophenol & 81.8 & 97.2 & $130^{\ddagger}$ & 49.0 \\
\hline Alkaline phosphatase $\mu \mathrm{g}$ p-nitrophenol & 78.2 & 47.0 & $85.2^{*}$ & 40.0 \\
\hline Cellulase $\mu$ g glucose equivalent & $22.8^{\dagger}$ & 3.86 & $19.2^{*}$ & 7.40 \\
\hline Chitinase $\mu \mathrm{g} N$-acetyl glucosamine & $6.66^{\dagger}$ & 5.93 & 6.28 & 6.31 \\
\hline Nitrification $\mu \mathrm{g} \mathrm{NO}$ & 44.6 & 72.5 & 64.9 & 48.2 \\
\hline Nitrogen fixation nmoles ethylene $\mathrm{hr}^{-1}$ & 0.228 & 0.316 & 0.223 & 0.318 \\
\hline Denitrification $\mathrm{ng} \mathrm{N}_{2} \mathrm{O}-\mathrm{N} \mathrm{h}^{-1}$ & & in fine-textured soil & $18.8^{\S}$ & 1.05 \\
\hline Denitrification $\mathrm{ng} \mathrm{N} \mathrm{N}_{2} \mathrm{O}-\mathrm{N} \mathrm{h}^{-1}$ & in coarse-textured soil & & 3.13 & 0.679 \\
\hline
\end{tabular}

Means designated ${ }^{*}$ and ${ }^{\dagger}$ and ${ }^{\ddagger}$ and ${ }^{\S}$ are significant at $P<0.05, P<0.01, P<0.001$ and $P<0.0001$ respectively. In the case of denitrification potential a significant soil $\times$ treatment interaction was present with the data presented by soil type and treatment as a result.
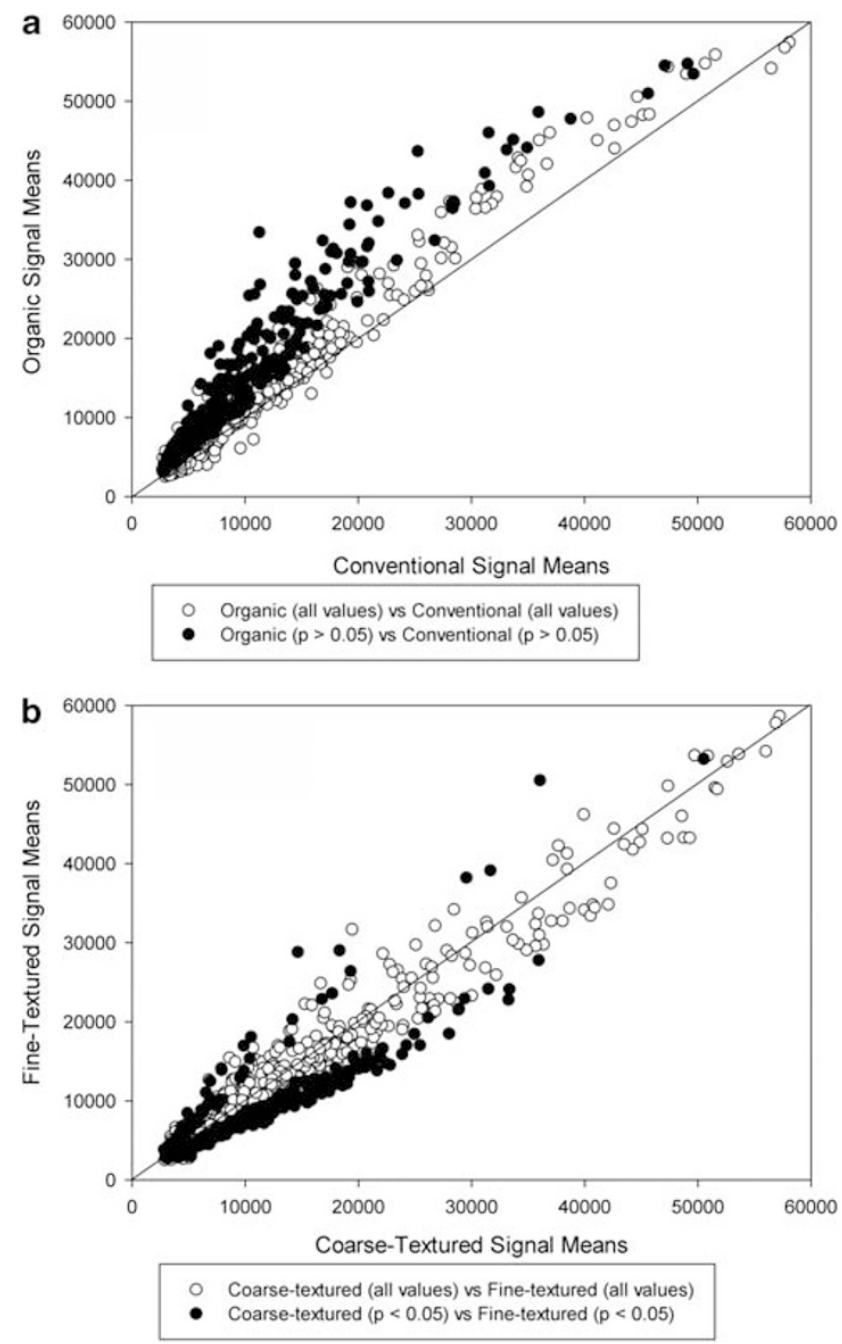

Figure 1 Comparison of microarray signal means according to management and soil type. (a) Comparison of microarray signal means from organically and conventionally managed soils, 553 of which were significantly $(P<0.05)$ greater in organically managed soils. (b) Comparison of signal means between coarse and finetextured soils, 505 of which were significantly $(P<0.05)$ different between soil types.
Signal intensity across all genes measured across each slide was on average significantly higher in organically managed soils (Supplementary Table S2). Summed SIs within functional gene categories for ureases, dehydrogenases, pesticide degradation, nitrification, sulfite reduction, xenobiotic degradation, metal resistance and reduction, cellulases, chitinases, dinitrogen fixation and denitrification pathway genes were significantly higher in organically farmed soils (Supplementary Table S2). Signal intensity summed across all genes or according to functional group showed no significant differences between coarse- and fine-textured soils (Supplementary Table S2). Gene diversity, as measured by Simpson's Reciprocal Diversity Index, was also significantly higher overall in organically managed soils (Supplementary Table S3). Gene diversity within functional groups was significantly greater in organically farmed soils for all measured functional groups with the exception of dehydrogenase.

Soil microbial biomass was significantly correlated with the sum of total SI and gene diversity, and potential cellulase activity in the soil was correlated with the sum of SI and diversity of cellulase genes (Table 2). There were notable correlations $(P<0.1)$ between dehydrogenase SI and potential dehydrogenase activity, urease SI and diversity with soil ammonium, and sulfite reduction SI and soil sulfur levels (Table 2). In addition, there were a large number of significant correlations between soil property and process data and various other functional gene SIs and diversity indices (Supplementary Table S4 and S5).

Non-parametric multivariate analysis produced similar results to the parametric analysis and correlations. Canonical correspondence analysis indicated that strawberry field management exerted a stronger influence $(r=0.313, P=0.006)$ than soil type $(r=0.283, P=0.022)$ on microbial composition (Supplementary Figure S2). Individual soil 
Table 2 Pearson Correlation Coefficients between microarray signal intensities and soil processes/chemistry

\begin{tabular}{|c|c|c|c|c|}
\hline Soil process/chemistry & Microarray signal intensity & $R$ value & Microarray gene diversity & $R$ value \\
\hline Cellulase activity & Cellulase & $0.589^{\dagger}$ & Cellulase & $0.450^{*}$ \\
\hline Microbial biomass & Overall sum & $0.581^{\dagger}$ & Overall sum & $0.567^{\dagger}$ \\
\hline Readily mineralizable C & Overall sum & $0.447^{*}$ & Overall sum & 0.387 \\
\hline Dehydrogenase activity & Dehydrogenase & $0.488^{*}$ & Dehydrogenase & -0.174 \\
\hline Ammonium & Urease & $-0.475^{*}$ & Urease & $-0.512^{*}$ \\
\hline Nitrification & Nitrification & 0.359 & Nitrification & 0.301 \\
\hline $\mathrm{N}_{2}$ fixation & $\mathrm{N}_{2}$ fixation & -0.352 & $\mathrm{~N}_{2}$ fixation & -0.171 \\
\hline Denitrification & Denitrification & 0.162 & Denitrification & 0.299 \\
\hline Total Soil N & Overall sum & -0.115 & Overall sum & 0.121 \\
\hline Total Soil C & Overall sum & 0.062 & Overall sum & 0.067 \\
\hline Chitinase activity & Chitinase & -0.004 & Chitinase & -0.059 \\
\hline
\end{tabular}

Means designated ${ }^{*},{ }^{\dagger}$, and ${ }^{\ddagger}$ are significant at $P<0.1, P<0.05$, and $P<0.01$, respectively.

properties of percent sand, $\mathrm{EC}, \mathrm{NH}_{4}^{+}, \mathrm{Mn}, \mathrm{B}$, and sulfur were also significantly associated $(P=0.005)$ with microbial community composition (Supplementary Figure S3). The Mantel test produced similar results (data not shown). Soil process data also explained a large proportion of the variability in microbial composition. The CCA model indicated connections between $\mathrm{N}$ fixation, denitrification, nitrification, chitinase, cellulase, readily mineralizable carbon and microbial biomass $(P=0.038)$, whereas the Mantel test indicated connections between cellulase, denitrification and microbial biomass, and detected microbial genes $\left(r_{\mathrm{M}}=0.352\right.$. $P=0.002$ ) (Supplementary Figure S4). Despite significant correlations for individual parameters, plotting matrices for soil process, soil property and microarray data against each other showed overall correlation was weak (Supplementary Figures S5 and S6).

\section{Discussion}

In agreement with our hypothesis, soil process measures indicated significantly greater soil quality and microbial activity in organically managed soils than in conventionally managed soils (Table 1 and Supplementary Table S1). Not only were soil processes shown to differ according to management, the FGA showed dramatic differences in microbial functional gene abundance and diversity. Signal intensity (SI) summed over all positive probes on the array was significantly greater on arrays hybridized with DNA from organically managed soils, as were all measured functional groups and $32 \%$ of individual genes that occurred in all treatments. In DNA hybridizations, SI is correlated with gene copy number and abundance of the organisms carrying these genes (Rhee et al., 2004), suggesting that detected functional genes and the organisms that carry them were more abundant in organically managed soils. As overall slide SI could also be related to DNA-labeling efficiency (DNA with higher incorporation of Cy5 dye would be more visible on the array irrespective of hybridization amount), it is important that labeling efficiencies are comparable. Label incorporation was similar between treatments (1.23 compared with $1.25 \mu \mathrm{mol}$ Cy $5 \mu \mathrm{l}^{-1}$ DNA solution respectively, $P=0.78$ ). As the same quantity of labeled DNA was applied to all slides, this shows the detected differences in SI were not introduced by differing labeling efficiencies.

Organically managed soils also contained more endemic genes, or genes detected in only one management type. Overall gene diversity was significantly greater on arrays hybridized with DNA from organically managed soils, indicating different composition of microbial functional genes between management types. When array genes were divided into 11 functional groups (genes linked to $\mathrm{N}$ fixation, nitrification, cellulose degradation, etc.), gene diversity was significantly greater in all measured functional groups from organically managed soils with the exception of dehydrogenase genes (Supplementary Table S3). This may simply reflect the low number (12) of gene variants present on the slide for dehydrogenase. Increased abundance and diversity of functional groups for resistance to metals and breakdown of xenobiotic compounds in organically managed soils might be taken to indicate increased levels of these substances in organically managed soils. However, there is no indication in field histories obtained from field owners and managers that would suggest increased soil contamination in organically managed fields. Moreover, the use of biosolids and most synthetic agrichemicals are prohibited under the USDA organic regulations. Rather, increased diversity in these genes is likely a reflection of the overall increased microbial abundance and genetic diversity in organically managed soils.

Several studies have shown organic management to increase microbial biomass and enzyme activity (Mäder et al., 2002) presumably due to use of organic fertilizers. However, studies linking these process level changes with the structure and diversity of the corresponding microbial biomass are rare. Differences of the magnitude measured in our study are also unusual. These large differences may be due to the yearly fumigation with methyl 
bromide and chlorpicrin of the conventionally managed fields in this study, although they also received compost at half the rate of the organically managed fields. It is often assumed that the soil microbial community makes a relatively rapid recovery from fumigation events especially if compost is added (Dungan et al., 2003). We propose that the long-term repeated use of fumigants may have more significant and lasting effects on soil microbial populations than have been measured in single fumigation event studies. Nevertheless it is impossible to determine the extent that the biological differences we measured resulted from fumigation, fertilization, synthetic pesticide use, etc., in conventionally managed fields or from organic amendments or even the allowed organic pesticides used in organically managed fields. Ibekwe (2004) suggested clayey soils might protect microorganisms somewhat from the effects of fumigation. Over the long term under field conditions, this does not appear to be the case. In fact, our data suggest that some genes are more affected by management on fine-textured soils (Supplementary Figure S1).

A key question in soil microbiology is whether perturbations of microbial biomass such as the repeated use of fumigation affect microbial diversity and soil processes (Smith, 2002). The answer may depend on the cause and severity of the perturbation. Although a number of studies using PLFA, DGGE and tRFLP methods have documented changes in microbial diversity due to fumigants and pesticides (Malcomes, 1995; Zelles et al., 1997; Engelen et al., 1998; Macalady et al., 1998; Dickens and Anderson, 1999; Ibekwe et al., 2001; Sigler and Turco, 2002). The majority of changes were relatively short lived with microbial populations tending to return to normal after a few weeks or months. These studies, however, were most often conducted in the laboratory with single fumigation events on soils with no regard to past history of fumigation or pesticide use. Also, showing a reduction or change in microbial diversity does not in itself imply that soil processes are affected. Research by Griffiths et al. (2001) indicated no effect on soil processes such as decomposition of grass clippings, nitrification and community level physiological profiling, despite decreases in microbial biomass by as much as $60 \%$ induced by soil fumigation.

Field studies provide a more robust answer to the question of whether perturbations lead to long-term changes in microbial communities and soil processes. Such studies are less common, and while they have shown at least short-term effects on soil processes, the results are inconsistent (Xiao and Duniway, 1998; Klose and Ajwa, 2004 and Stromberger et al., 2005). Each of these published field studies (with annual fumigation events) were conducted over 2-3 years and only on soils with no immediate pre-history of fumigation. None of these studies considered the cumulative effect of repeated fumigation on microbial recovery or resilience.
Griffiths et al. (2000) showed that resilience of microbial communities to further stress events was reduced after chloroform fumigation. Our study was conducted on fields with longer histories (at least 5 years) of both organic and conventional management (with annual fumigation), likely contributing to the detection of persistent effects on both soil processes and microbial populations.

Previous farming system comparisons have indicated soil type as opposed to management as a greater determining factor on microbial activity and diversity (Bossio et al., 1998; Girvan et al., 2003). These studies did not include systems using fumigants, and some managements were only in place for 1-2 years. Soil type affected many chemical soil properties in our study, but only denitrification, cellulose and chitinase activity differed by soil type among the measured biological properties. Functional gene diversity and SI also differed by soil type but the effect of management was stronger.

Microbial biomass is often correlated with soil organic carbon, with clayey soils typically higher in microbial biomass than sandy soils (Kaiser et al., 1992; Hassink, 1994; Franzluebbers et al., 1996). However, microbial biomass may be more highly correlated with active carbon than total C (Weil et al., 2003). This is supported by our findings that many of the biological processes and molecular data are more strongly correlated with readily mineralizable C than total C (Table 2, Supplementary Table S4 and S5). Fine-textured and organically managed soils (Table 1) had greater total C than their coarsetextured or conventionally managed counterparts, but greater microbial resource use efficiency (lower $\mathrm{qCO}_{2}$ ) and a trend towards greater readily mineralizable $\mathrm{C}$ was only observed in the organically managed soils. This suggests much of the $\mathrm{C}$ in the fine-textured soils was recalcitrant with greater levels of active carbon in the organically managed soils only. Similarly, both organically managed and fine-textured soils had more total $\mathrm{N}$ than their counterparts but only organically managed finetextured soils showed greater denitrification potential. This suggests that the conventionally managed fields had less active $\mathrm{C}$ and $\mathrm{N}$ likely because they received half the rate of compost as the organically managed fields. These potential differences in active $C$ levels combined with the ongoing effects of fumigation appear to have resulted in management exerting a stronger influence on biological properties than soil type.

A positive correlation between overall slide SI and microbial biomass as measured by substrateinduced respiration seems to reinforce the validity of the two techniques for detecting microbial abundance in soils. A significant correlation between cellulase gene SI and cellulase activity in the soil, and the notable $(P<0.1)$ correlations between dehydrogenase gene SIs and activity, urease gene SIs and soil ammonium, and sulfite reduction gene 
SIs and soil sulfur levels, also point to a relationship between gene copy number and soil function. Yergeau et al. (2007) also showed a significant correlation between cellulase enzyme activity and the number of cellulase gene variants detected using FGAs.

Multivariate analyses supported the findings generated using ANOVA and Pearson correlations, with cellulase and SIR significantly correlated with microbial gene composition using both CCA and Mantel tests (Supplementary Figure S4). These results support our hypotheses that functional gene analysis and traditional process measurements do corroborate each other for individual parameters, although overall correlations were weak (Supplementary Figures S5 and S6). Multivariate tools are commonly used in ecology and are beginning to gain popularity in the microbial ecology literature (Zhou et al., 2008). Although summary indices like diversity can provide descriptions of the community or portions thereof, multivariate statistics may make inferences from the community as a whole and its relationship with its environment.

A large component of the soil microbial population may be inactive. Soil DNA hybridizations cannot differentiate between active and inactive microbial cells, and potential contributions to SI of inactive (for example, spores or dead biomass) or damaged copies of genes cannot be determined. For this reason, caution should be used when interpreting DNA FGAs (Gentry et al., 2006). To overcome this criticism researchers are beginning to use RNA for environmental microarray analysis (Rhee et al., 2004; Gao et al., 2007). As most soil process techniques measure potential activity under ideal conditions (not actual field activities), we would suggest the DNA- and RNA-based techniques are complementary. Correlations between traditional techniques and soil DNA might be stronger than with soil mRNA because DNA may better represent the potential functional capability of the microbial biomass rather than its current and presumably transient state represented by mRNA.

Although there is growing literature on the use of microarray analysis of environmental samples, the majority of studies have been proof of concept papers that did not provide sufficient samples in a robust statistical design to draw meaningful conclusions (Gentry et al., 2006). For this reason few ecologically relevant questions have as yet been answered with the use of microarrays. One notable exception is the study by Stralis-Pavese et al. (2004), which detected differences in methanotroph populations in response to landfill biogas and vegetation cover using a FGA targeting particulate methane monooxygenase genes. More recently large-scale relationships between genes and environmental processes and community level spatial relationships using FGAs have been shown (Yergeau et al., 2007; Wu et al., 2008; Zhou et al., 2008).

To our knowledge, this study is the first to investigate the use of a comprehensive FGA to analyze the role of microbial functional gene abundance and diversity on soil processes using a randomized and replicated statistical design. Using the FGA we were able to show that the reduced soil processes in the conventionally farmed fields were associated with decreased microbial gene abundance and diversity. These differences were detected nearly a year after the last fumigation event, indicating that the potential and resilience of the microbial community was affected by the longterm and ongoing management systems including fumigation of conventionally managed fields. The role of active $\mathrm{C}$ in supporting diverse and abundant microbial communities is likely. A trend towards increased active $\mathrm{C}$ was found only in organically managed soils despite the conventional fine-texture soils also being high in total C. This suggests that high levels of organic inputs can result in management exerting a stronger influence than soil type on microbial communities that are greatly affected by active C. Significant correlations between functional gene signal intensity and their corresponding soil function provides further corroboration of the validity of both traditional soil process measurements and FGAs and shows the power of a robust combined approach in investigating microbial processes in soils.

\section{Acknowledgements}

This work was funded by The Organic Center (http:// www.organic-center.org). Microarray analysis and the participation of Dr's Schadt and Zhou was supported by The United States Department of Energy under the Environmental Remediation Science Program, and Genomics: GTL program through the Virtual Institute of Microbial Stress and Survival (VIMSS; http://vimss.lbl.gov), Office of Biological and Environmental Research, Office of Science, and by the United States Department of Agriculture through NSF-USDA Microbial Observatories Program. We thank Tom Sjulin of Driscoll's Strawberry Associates and Larry Eddings of Pacific Gold Farms for assistance with farm selection. A special thanks to Drs Jan Dasgupta and Stuart Higgins for help and advice on statistical analysis. Additional thanks to Debbi Bikfasy, Margaret Davies, Mary Fauci and Emily Hollister for training and advice in lab protocols.

\section{References}

Alef K, Nannipieri P. (1995a). Cellulase activity. In: Alef K., Nannipieri P. (eds.). Methods of Applied Microbiology and Biochemistry. Academic Press Inc: San Diego, CA, pp 346-347.

Alef K, Nannipieri P. (1995b). Estimation of nitrogenase activity of free-living bacteria in soils. In: Alef K., Nannipieri P. (eds.). Methods of Applied Microbiology and Biochemistry. Academic Press Inc: San Diego, CA, pp 243-245. 
Anderson JPE, Domsch KH. (1978). A physiological method for the quantitative measurement of microbial biomass in soil. Soil Biol Biochem 10: 215-221.

Bodrossy L, Stralis-Pavese N, Murrell JC, , Radajewski S, , Weilharter A, Sessitsch A. (2003). Development and validation of a diagnostic microbial microarray for methanotrophs. Environ Microbiol 5: 566-582.

Bossio DA, Scow KM, Gunapala N, Graham KJ. (1998). Determinants of soil microbial communities: effects of agricultural management, season, and soil type on phospholipid fatty acid profiles. Microb Ecol 36: 1-12.

California Strawberry Commission (2009) California Strawberry Commission Website. Available: www. calstrawberry.com/. Accessed on 27 Nov 2009.

Dickens HE, Anderson JM. (1999). Manipulation of soil microbial community structure in bog and forest soils using chloroform fumigation. Soil Biol Bioch 31: 2049-2058.

Dungan RS, Ibekwe AM, Yates SR. (2003). Effect of propargyl bromide and 1,3-dichloropropene on microbial communities in an organically amended soil. FEMS Microb Ecol 43: 75-87.

Engelen B, Meinken K, von Wintzingerode F, Heuer H, Malkomes H-P, Backhaus H. (1998). Monitoring impact of a pesticide treatment on bacterial soil communitites by metabolic and genetic fingerprinting in addition to conventional testing procedures. Appl Environ Microbiol 64: 2814-2821.

Fitter AH, Gilligan CA, Hollingworth K, Kleczkowski A, Twyman RM, Pitchford JW. (2005). Biodiversity and ecosystem function in soil. Funct Ecol 19: 369-377.

Franzluebbers AJ, Haney RL, Hons FM, Zuberer DA. (1996). Active fraction of organic matter in soils with different texture. Soil Biol Biochem 28: 1367-1372.

Gao H, Yang ZK, Gentry TJ, Wu L, Schadt CW, Zhou J. (2007). Microarray-based analysis of microbial community RNAs by whole-community RNA amplification. Appl Environ Microbiol 73: 563-571.

Gentry TJ, Wickham GS, Schadt CW, He Z, Zhou J. (2006). Microarray applications in microbial ecology research. Microb Ecol 52: 159-175.

Girvan MS, Bullimore J, Pretty JN, Osborn AM, Ball AS. (2003). Soil type is the primary determinant of the composition of the total and active bacterial communities in arable soils. Appl Environ Microbiol 69: 1800-1809.

Griffiths BS, Ritz K, Bardgett RD, Cook R, Christensen S, Ekelund $\mathrm{F}$ et al. (2000). Ecosystem response of pasture communities to fumigation-induced microbial diversity reductions: an examination of the biodiversity- ecosystem function relationship. OIKOS 90: 279-294.

Griffiths BS, Ritz K, Wheatley R, Kuan HL, Boag B, Christensen S et al. (2001). An examination of the biodiversity-ecosystem function relationship in arable soil microbial communities. Soil Biol Bioch 33: 1713-1722.

Hassink J. (1994). Effect of soil texture on the size of the microbial biomass and on the amount of $\mathrm{C}$ and $\mathrm{N}$ mineralized per unit of microbial biomass in Dutch grassland soils. Soil Biol Biochem 26: 1573-1581.

He Z, Gentry TJ, Schadt CW, Wu L, Liebich J, Chong SC et al. (2007). GeoChip: a comprehensive microarray for investigating biogeochemical, ecological and environmental processes. ISME J 1: 67-77.

Ibekwe AM. (2004). Effects of fumigants on non-target organisms in soils. Adv Agron 83: 1-35.
Ibekwe AM, Papiernik SK, Gan J, Yates SR, Yang C-H, Crawley DE. (2001). Impact of fumigants on soil microbial communities. Appl Environ Microbiol 67: 3245-3257.

Kaiser EA, Mueller T, Joergensen RG, Insam H, Heinemeyer O. (1992). Evaluation of methods to estimate the soil microbial biomass and the relationship with soil texture and organic matter. Soil Biol Biochem 24: 675-683.

Kelly JJ. (2003). Molecular techniques for the analysis of soil microbial processes: functional gene analysis and the utility of DNA microarrays. Soil Sci 168: 597-605.

Klose S, Ajwa HA. (2004). Enzyme activities in agricultural soils fumigated with methyl bromide alternatives. Soil Biol Biochem 36: 1625-1635.

Koizumi Y, Kelly JJ, Nakagawa T, Urakawa H, ElFantroussi S, Al-Muzaini S et al. (2002). Parallel characterization of anaerobic toluene and ethylbenzene degrading microbial consortia by PCR-denaturing gradient gel electrophoresis, RNA-DNA membrane hybridization and DNA microarray technology. Appl Environ Microbiol 68: 3215-3225.

Liebich J, Schadt CW, Chong SC, He Z, Rhee SK, Zhou J. (2006). Improvement of oligonucleotide probe design criteria for functional gene microarrays in environmental applications. Appl Environ Microbiol 72: 1688-1691.

Little AEF, Robinson CJ, Peterson SB, Raffa KE, Handelsman J. (2008). Rules of engagement: interspecies interaction that regulate microbial communities. Annu Rev Microbiol 62: 375-401.

Loy A, Lehner A, Lee N, Adamczyk J, Meier H, Schleifer $\mathrm{K}-\mathrm{H}$ et al. (2002). Oligonucleotide microarray for $16 \mathrm{~s}$ rRNA gene based detection of all recognized lineages of sulfate-reducing prokaryotes in the environment. Appl Environ Microbiol 68: 5064-5081.

Macalady JM, Fuller ME, Scow KM. (1998). Effects of metam sodium fumigation on soil microbial activity and community structure. J Environ Soil Qual 27: 54-63.

Mäder P, Fleissbach A, Dubois D, Gunst L, Fried P, Niggli U. (2002). Soil fertility and biodiversity in organic farming. Science 296: 1694-1697.

Malcomes HP. (1995). Ecotoxicology of soil fumigation. Effects of methyl bromide on microbial activities in soil under field conditions. J Plant Dis Prot 102: 606-617.

Reganold JP, Palmer AS, Lockhart JC, Macgregor AN. (1993). Soil quality and financial performance of biodynamic and conventional farms in New Zealand. Science 260: 344-349.

Rhee S-K, Liu X, Wu L, Chong SC, Wan X, Zhou J. (2004). Detection of genes involved in biodegradation and biotransformation in microbial communities by using 50-mer oligonucleotide microarrays. Appl Environ Microbiol 70: 4303-4317.

Rössner H. (1995). Chitinase activity. In: Alef K, Nannipieri P (eds.). Methods in Applied Soil Microbiology and Biochemistry. Academic Press: San Diego, CA, pp 360-361.

Schmidt EL, Belser LW. (1994). Autotrophic nitrifying bacteria. In: Weaver RW et al. (eds.). Methods of Soil Analysis Part 2-Microbiological and Biochemical Properties. Soil Sci. Soc. of Am: Madison, WI, pp 171-172.

Sigler WV, Turco RF. (2002). The impact of chlorothalonil application on soil bacterila and fungal populations as assessed by denaturing gradient gel electrophoresis. Appl Soil Ecol 21: 107-118. 
Smith JL. (2002). Soil quality: the role of microorganisms. In: Bitton G. (ed.). Encyclopedia of Environmental Microbiology. John Wiley \& Sons: New York, NY, pp 2944-2957.

Stralis-Pavese N, Sessitsch A, Weilharter A, Reichenauer T, Riesing J, Csontos J et al. (2004). Optimization of diagnostic microarray for application in analyzing landfill methanotroph communities under different plant covers. Environ Microbiol 6: 347-363.

Stromberger ME, Klose S, Ajwa H, Trout T, Fennimore S. (2005). Microbial populations and enzyme activities in soils fumigated with methyl bromide alternatives. Soil Sci Soc Am J 69: 1987-1999.

Tabatabai MA. (1994). Soil enzymes. In: RW Weaver et al. (eds.) Methods of Soil Analysis. Part 2, Microbiological and Biochemical Properties. Soil Sci Soc of Am: Madison, WI, pp 775-833.

Tiedje JM. (1994). Denitrifiers. In: R.W. Weaver et al (eds.). Methods of Soil Analysis Part 2, Microbiological and Biochemical Properties. Soil Sci Soc Am: Madison, WI, pp 256-257.

Torsvik V, Goksoyr J, Daale FL. (1990). High diversity in DNA of soil bacteria. Appl Environ Microbiol 56: 782-787.

Weil RR, Islam KR, Stine MA, Gruver JB, Samson-Liebig SE. (2003). Estimating active carbon for soil quality assessment: a simplified method for laboratory and field use. Am J Alternative Agric 18: 3-17.

Wu L, Kellogg L, Devol AH, Palumbo AV, Tiedje JM, Zhou J. (2008). Microarray-Based characterization of microbial community functional structure and heterogeneity in marine sediments from the gulf of Mexico. Appl Environ Microbio 74: 4516-4529.

Wu L, Liu X, Schadt CW, Zhou J. (2006). Microarray-based analysis of subnanogram quantities of microbial community DNAs by using whole-community genome amplification. Appl Environ Microbiol 72: 4931-4941.

Xiao CL, Duniway JM. (1998). Bacterial population response to soil fumigation and their effects on strawberry growth. Phytopathology 88(suppl.): S100.

Yergeau E, Kang S, He Z, Zhou J, Kowalchuk GA. (2007). Functional microarray analysis of nitrogen and carbon cycling genes across an Antarctic latitudinal transect. The ISME J, 1-17.

Zelles L, , Palojarvi A, , Kandeler E, von Lutzow M, Winter K, Bai QY. (1997). Changes in soil microbial properties and phospholipid fatty acid fractions after chloroform fumigation. Soil Biol Biochem 29: 1325-1336.

Zhou J, Kang S, Schadt CW, Garten Jr CT. (2008). Spatial scaling of functional gene diversity across various microbial taxa. Proc Nat Acad Sci 105: 7768-7773.

Supplementary Information accompanies the paper on The ISME Journal website (http://www.nature.com/ismej) 